\title{
Knowledge Mapping of Homeowners' Retrofit Behaviors: An Integrative Exploration
}

\author{
Guo Liu ${ }^{1, *}$, Yongtao Tan ${ }^{2, *(\mathbb{D})}$ and Zhijia Huang ${ }^{1}$ \\ 1 School of Civil Engineering and Architecture, Anhui University of Technology, Ma'anshan 243002, China; \\ hzj@ahut.edu.cn \\ 2 School of Engineering, RMIT University, GPO Box 2476, Melbourne, VIC 3001, Australia \\ * Correspondence: lgjycqu@163.com (G.L.); yongtao.tan@rmit.edu.au (Y.T.)
}

check for updates

Citation: Liu, G.; Tan, Y.; Huang, Z. Knowledge Mapping of

Homeowners' Retrofit Behaviors: An Integrative Exploration. Buildings 2021, 11, 273. https://doi.org/ 10.3390/buildings11070273

Received: 4 June 2021

Accepted: 24 June 2021

Published: 26 June 2021

Publisher's Note: MDPI stays neutral with regard to jurisdictional claims in published maps and institutional affiliations.

Copyright: (C) 2021 by the authors Licensee MDPI, Basel, Switzerland. This article is an open access article distributed under the terms and conditions of the Creative Commons Attribution (CC BY) license (https:// creativecommons.org/licenses/by/ $4.0 /)$

\begin{abstract}
Energy retrofitting of existing residential buildings has a great potential to achieve a sustainable future. One important way to reach this potential is to understand homeowners' retrofit behaviors due to their crucial roles in retrofit adoption and retrofit effects. Despite many attempts, researchers and governments still know less about the holistic profile of homeowners' retrofit behaviors, which brought little success in trigging renovation activities and achieving expected retrofit effects. This study tries to fill this research gap by a comprehensive review of the body of existing research. A keyword-based scientometric analysis was performed based on a set of 152 journal articles. By further refining keywords, main research domains pertaining to investment-decision-energy behaviors, policy instruments, retrofit types, construction \& services, and methods \& methodologies were mapped to show relevant research knowledge and research topics. Based on these research results, a further integrated framework was developed, which explains homeowners' retrofit behaviors in a systematic way of cross-disciplinary knowledge interactions. Furthermore, implications for retrofit policies in existing buildings were provided. This study is useful for facilitating future research to deepen homeowners' retrofit behaviors, and also provides valuable references for policy makers to successfully promote home energy retrofit.
\end{abstract}

Keywords: existing residential buildings; energy retrofit; knowledge mapping; integrative framework

\section{Introduction}

Global energy consumption in existing buildings is a main contributor to serious resource scarcity and climate change. Such energy consumption will rise nearly threefold worldwide by 2100 [1], calling for global great efforts to improve energy efficiency of building stock. Energy retrofitting of existing buildings can reduce their energy consumption from $45 \%$ up to $70 \%$ [2], which has been considered as an effective way to mitigate above issues [3]. Among the existing buildings, residential buildings, accounting for a high ratio (e.g., about 70\% of the European building stock) [4], have the greatest potential for energy performance improvements $[2,5]$. Promoting energy retrofit in existing residential buildings is consequently a key path to achieve a sustainable future.

The homeowner plays a dominating role in promoting housing energy retrofit and affecting energy efficiency of retrofitted houses [6]. First of all, homeowners are fundamental for initiating renovation activities [7-9]. In other words, homeowners can basically decide whether to carry out renovation of their houses. If homeowners resist home renovation activities, it would be almost impossible to promote renovation at a large scale. In addition, homeowners may exert great influence on home energy consumption after the retrofitting [10], which is especially significant in owner-occupied houses [9]. A typical case of such influence is the "energy-saving gap"-homeowners' mismatched energy behaviors result in lower energy saving than expected in retrofitted houses [11,12]. With reference to Serrano-Jiménez, et al. [13], such behaviors can cause up to $80 \%$ energy saving 
variations for the same retrofitting action. As a result, understanding homeowners' retrofit behaviors (i.e., retrofit decision-making) is essential to successfully implement home energy retrofit worldwide.

A growing number of studies on homeowners' retrofit behaviors have been carried out. Examples of these studies include homeowners' perceptions [14], motivations [15], intentions [16], preferences [17], attitudes of house energy retrofit [18], renovation decisionmaking process [19], and relevant drivers, barriers and other factors (e.g., property characteristics, energy audit) [20-22]. These studies are conducted from a wide range of disciplinary perspectives, including microeconomics (e.g., utility theory), behavioral economics (e.g., individual preferences), technology adoption (e.g., diffusion theories), psychology (e.g., the theory of planned behavior), and sociology (e.g., lifestyles, social network), etc.

Despite various studies, the process towards to homeowners' retrofit behaviors remains ongoing challenges due to the theoretical preferences of various disciplines [23], such as the economic perspective emphasizing utility maximization and psychology placing an emphasis on individual internal factors. The single analytical approach cannot provide a holistic understanding of homeowners' renovation behaviors, bringing little success of retrofit policies in triggering retrofit activities [24]. Kastner and Stern [25] pointed out that homeowners' renovation behavior is a multidisciplinary research topic needing an integrative knowledge exploration. However, there is a dearth of a combination of various domain-specific findings on homeowners' retrofit behavioral studies. Few of available studies investigate and summarize what is known about the basis of homeowners' renovation behaviors, including behavior characteristics, research domains/focuses, guideline measures, and theoretical framework, which lays a sold fundamental for a deep understanding of homeowners' renovation behaviors. To fill this gap, a comprehensive review based on a preliminary scientometric analysis is carried out to support development of a knowledge roadmap and an integrative theoretical framework on homeowners' renovation behaviors. Such review might be of use to better understand homeowners' renovation behaviors and consequently to enhance the effectiveness of policy measures in promoting home energy-related investment and environment-friendly energy consumption behaviors.

\section{Research Methodology}

\subsection{The Research Scope}

Residential buildings can be generally divided into owner-occupied housing and renting house. For these two house types, owners' retrofit behaviors, such as investment behaviors, are different and should not be treated as the same [26]. The significant feature of owner-occupied housing is that the homeowners who initiate their home renovation are the occupants who live in the home before, during and after the retrofitting [12]. Such kind of house type has a high proportion. For example, the Dutch owner-occupied sector accounts for $69.4 \%$ of the building stock [27]; around $67 \%$ of UK homes are owner-occupied [8]; and $80 \%$ of all dwellings are owned privately in Germany [26]. As a result, owner-occupiers have been widely researched, the focus of homeowners in this study therefore especially refers to owner-occupiers.

An increasing body of studies investigate and examine homeowners' retrofit behaviors. The majority of studies pay attention to owners' investment decision-making behaviors of pre-retrofit. They focus largely on barriers that demotivating homeowners to initiate home renovation, drivers that motivate homeowners to embark home renovation, decision process, and decision support systems [28-32]. Part of studies place an emphasis on homeowners' participation in the process of renovation activities, especially on the stage of retrofit design [33-35]. Such research stresses that renovation strategies need to suit occupants' energy practices and energy-saving effects might not be the only goal of housing renovation. They also advocate that individual non-energy requirements, such as comfort, aesthetic, and do-it-yourself (DIY), can be taken into consideration in pre-retrofit design. Another research branch concerns homeowners' energy use behaviors after housing renovation, which explore the effects (e.g., prebound effects and rebound effects) of 
energy behaviors on renovation results and behavior-related intervention measures mainly through the lens of social practices [36,37]. Based on these studies, homeowners' retrofit behaviors in this study refer to homeowners' various behaviors throughout the whole process of home renovation, covering investment decision-making behaviors of pre-retrofit, participation behaviors during retrofit process, and energy use behaviors of post-retrofit.

\subsection{Data Collection}

In order to capture the literature on homeowners' retrofit behaviors, a holistic and systematic literature search was carried out (see Figure 1) in April 2020 in the Scopus database for its wider ranges of scientific literature and more modern sources than other databases $[24,38,39]$. Multiple alternative search terms for homeowners' retrofit behaviors, including residential building, house, home, renovation, retrofit, homeowner, household, occupant, decision, investment, energy, and energy efficiency, etc., were tried several times by different terms combinations. This results in a largest volume of more than 3000 papers. By looking through the titles of collected journal papers, the search terms were revised to increase the number of relevant papers and decrease the number of irrelevant papers in the findings. Finally, the search terms, including retrofit* ${ }^{*}$, renovat ${ }^{*}$, refurbishment, rehabilitation, residential building, house, residence, dwelling, home, apartment, flat, owner, household, decision ${ }^{*}$, invest* ${ }^{*}$, and energy efficiency were adopted, and 546 journal papers in English were obtained. To ensure these papers focusing on homeowners' retrofit behaviors, two-round literature screening were conducted. In the screening process, a volume of papers about building retrofit effects and technical assessment not regarding owners were excluded. In order to avoid missing important literature in the field, the literature set was supplemented through the reference retrospective of collected latest papers. Finally, 152 valid papers were obtained. These papers span 38 years from 1983-2020. Among them, papers from $2015-2020$ account for $65.13 \%$. The distribution of these papers in different scholarly journals were summarized in Table 1.

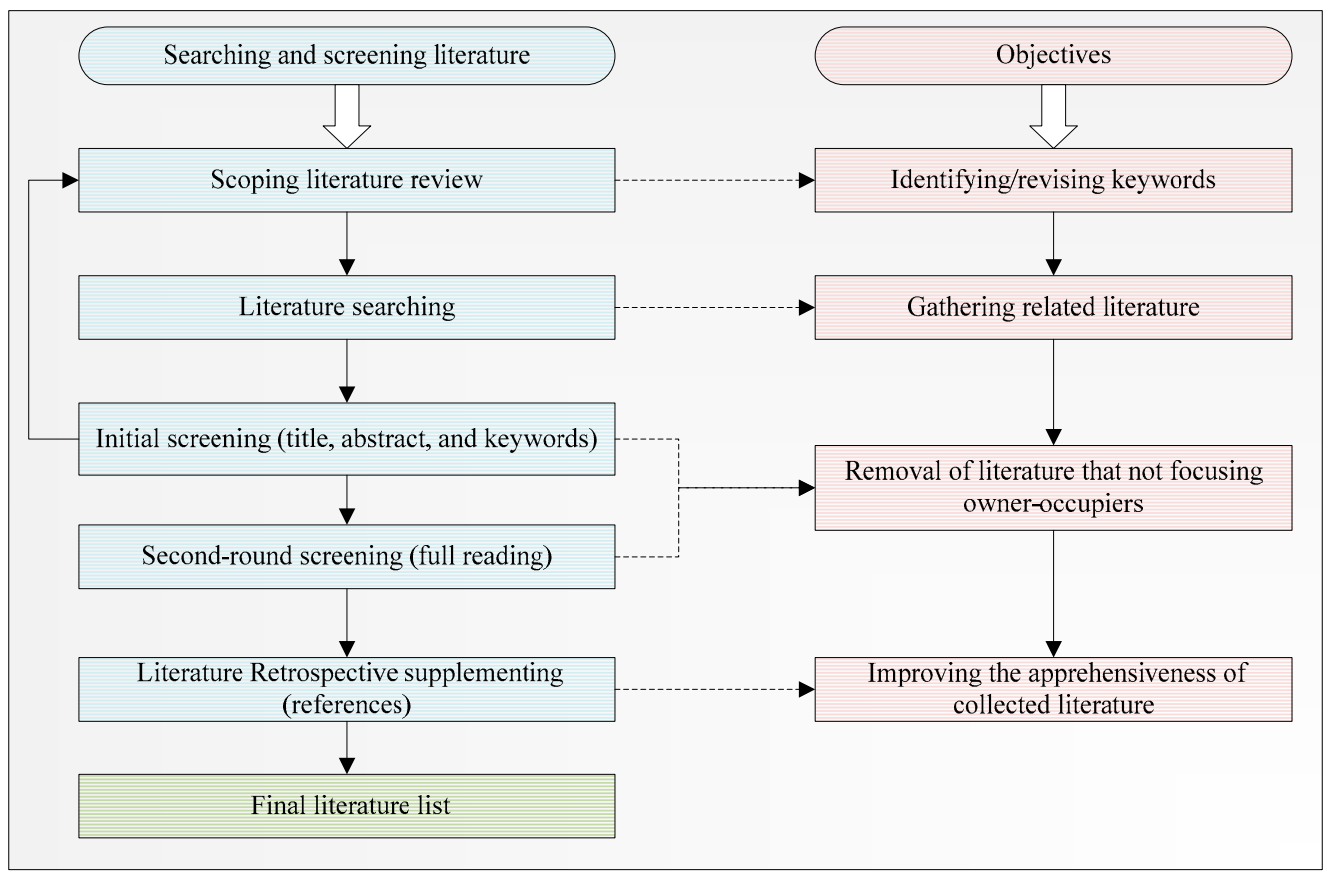

Figure 1. The process of data collection. 
Table 1. Distribution of collected papers in journals.

\begin{tabular}{lll}
\hline Journal & No. of Papers & Percentage \\
\hline Energy Policy & 19 & $12.50 \%$ \\
Energy and Buildings & 17 & $11.18 \%$ \\
Building Research and Information & 16 & $10.53 \%$ \\
Energy Research and Social Science & 11 & $7.24 \%$ \\
Energy Efficiency & 9 & $5.92 \%$ \\
Building and Environment & 6 & $3.95 \%$ \\
Applied Energy & 6 & $3.95 \%$ \\
Sustainable Cities and Society & 5 & $3.29 \%$ \\
Journal of Cleaner Production & 4 & $2.63 \%$ \\
Sustainability & 4 & $2.63 \%$ \\
Buildings & 3 & $1.97 \%$ \\
Energy Economics & 2 & $1.32 \%$ \\
Ecological Economics & 2 & $1.32 \%$ \\
Historic Environment: Policy and Practice & 2 & $1.32 \%$ \\
Structural Survey & 2 & $1.32 \%$ \\
Journal of Environmental Planning and Management & 2 & $1.32 \%$ \\
Open House International & 2 & $1.32 \%$ \\
Others & 40 & $26.32 \%$ \\
\hline
\end{tabular}

It is worth noting that in the process of literature screening, a large number of articles refer to owners, but the specific type of owners (e.g., owner-occupiers or landlords) is vague. Considering the large percentage of owner-occupied housing, it is hypothesized in this study that these papers are involving owner-occupiers' retrofit behaviors if there is no clear indication of focusing on landlords' or other types of owners' renovation.

\subsection{Research Methods}

To review and examine homeowners' retrofit behaviors, a keyword-based scientometric analysis is employed to preliminarily summarize the 152 samples in this study. First of all, the analysis can map and visualize specific knowledge themes in a networked way [40]. The network consists of nodes and edges, where nodes can be for example keywords, authors, or papers; the edges show relations (e.g., co-occurrence relations, relation strength) between nodes [41]. For various types of nodes, keywords are refined from the main contents of existing studies to convey a specific research topic in given knowledge domains $[40,42]$. A network of keyword co-occurrences may display the distribution of knowledge and their relations in different literature [43], which lays a foundation for subsequent comprehensive review in an integrated way. Second, the method can automatically extract keywords from the titles and the author-supplied keywords lists of literature by computer tools, which, to some extent, can overcome the inefficiency of manual processing of volumes of sample data. Third, the keyword-based scientometric analysis has been extensively applied to depict sharing knowledge themes in previous studies $[39,40]$, which is feasible to achieve the aim of this study.

Various analysis tools (e.g., CiteSpace, R package, VOSViewer) are available for keyword-based scientometric analysis. Some existing studies in the field of sustainable buildings have adopted CiteSpace to assist the literature review of various topics, such as low carbon building [40] and green Building [44]. With reference to these studies, CiteSpace [45] is adopted to review and examine the mainstream of literature on homeowners' retrofit behaviors in this study. To meet the data requirements of CiteSpace, Notepad++, a code editor, is employed to help check and revise literature samples' formats.

This study also attempts to make a clustering analysis to depict research domains of homeowners' retrofit behaviors. At first, a clustering analysis by CiteSpace is made. The clustering results are quite different by different algorithms and their indicators are not ideal. Considering the limitations of clustering analysis by CiteSpace [40], keywords identified by CiteSpace are further clustered by the research group. Manual cluster may 
be criticized for subjective bias issues; however, the consistent perception of research group members is adopted to remove such bias. In addition, more than $80 \%$ of identified keywords have obvious difference, which is a good prerequisite for effective manual classification in this study. Most importantly, the clustering analysis in this study is coarsegrained in order to provide a preliminary framework of homeowners' retrofit behaviors. As a result, it is feasible to make a manual clustering. The classification is in line with the following principles. First, keywords that are semantically similar are grouped, such as retrofit, renovation, and refurbishment. Second, the cluster labels are set based on the keywords of top-ranked frequencies. Third, to explore research basis and means, a category of "theory and methodology" is originated, which including research perspectives, theories, methods, and tools. Fourth, in line with aforementioned definition of homeowners' retrofit behaviors, investment, decision and other retrofit behaviors are categorized as a group (investment-decision-energy behaviors).

\section{Results}

\subsection{Co-Occurrence of Keywords}

A visual keywords co-occurrence network based on articles' titles and keywords is pictured by CiteSpace. Initially, 1 was set as the threshold of minimum occurrence of a keyword to give a full picture of all keywords. For this threshold, nearly 500 keywords were derived. In the keyword set, some terms have the same semantic meanings, such as "decision-making" versus "decision making", and "retrofit" versus "retrofitting". These terms were combined in the second-round keyword analysis. Finally, a visual keywords co-occurrence network, consisting of 463 nodes and 1164 links, was generated and is displayed in Figure 2.

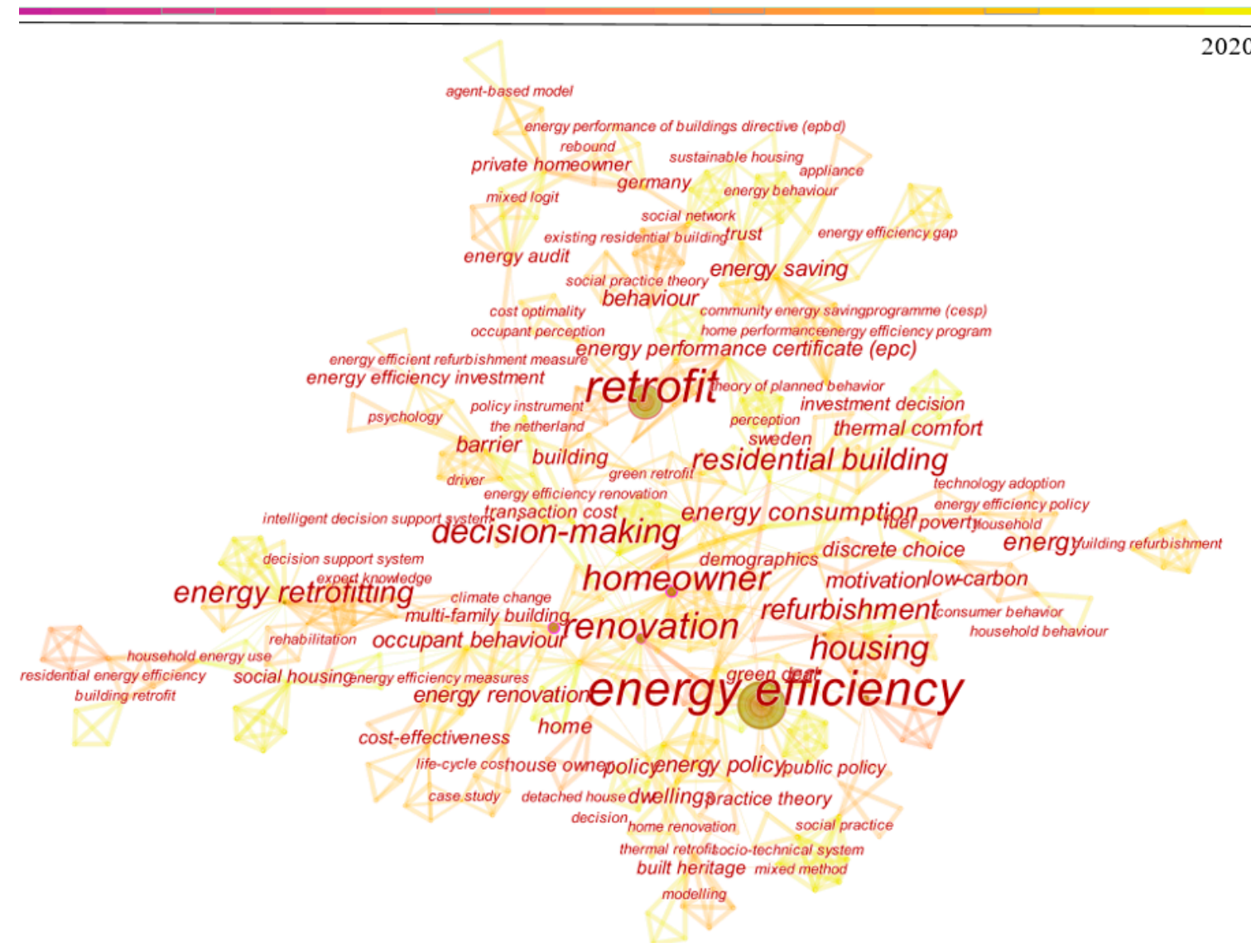

Figure 2. Keywords co-occurrence network. 
In Figure 2, each node represents a keyword and the node size reflects the cooccurrence frequency of a keyword; the link between two nodes indicates that the two keywords co-occur in one paper; the colors and thickness of links respectively represent the time and the frequencies of two-keyword co-occurrence. Based on such network, keywords, their co-occurrence frequencies, and their centralities were obtained. It can be found that the term of energy efficiency has the highest frequencies with 53, followed by retrofit (41), renovation (17), homeowner (16), decision-making (15), housing (14), and residential building (10). These terms are connected in a network, transcending the limitations of specific disciplines. Especially, the term of homeowner has the largest centrality with 0.49 , indicating homeowner bridges multiple research topics. Such frequency and centrality show that literature searching results are in the expected scope of homeowners' retrofit behaviors, to some extent demonstrating the effectiveness of collected literature.

\subsection{Research Domains}

By screening all identified 463 keywords, it is found that 351 keywords with 666 co-occurrence frequencies can be categorized as seven groups, namely energy and sustainability, housing retrofit, owners, theory and methodology, investment-decision-energy behaviors, policy instruments, and construction and services. These groups account for $75.81 \%$ of total keywords and $84.41 \%$ of the total co-occurrence frequencies respectively. The uncategorized keywords refer mainly to countries/regions, technology measures, or vague terms (e.g., strategy, standard, recommendation). Considering that such keywords are scattered and most of them have 1 frequency, they are not further analyzed in this study.

Three clusters including "energy and sustainability", "housing retrofit" and "owners" are the focus of literature searching, which cover 134 keywords and 353 keyword cooccurrence frequencies. Among them, the cluster of housing retrofit, referring to housing, retrofit, renovation types (e.g., physical retrofit), and renovation process, is the largest one, which has 83 keywords (accounting for $23.65 \%$ of selected 351 keywords) and 205 keywords co-occurrence frequencies (accounting for 30.78\% of 666 co-occurrence). Besides these, the most significant cluster is "theory and methodology". It owns the largest number of keywords (92, accounting for $26.21 \%$ ), covering various research theory (e.g., social practice theory, theory of planned behavior) and research methods (e.g., discrete choice, mixed logit, optimization model). The other clusters including "investment-decisionenergy behaviors", "policy instruments", and "construction and services" are the main research topics. A total of 67 keywords (19.09\%) including decision-making, investment decision, decision, motivation, barrier, energy efficiency investment, behavior, occupant behaviors are included in the cluster of investment-decision-energy behaviors. Clusters of "policy instruments" and "construction and services", with a proportion of $16.52 \%$ of selected 351 keywords and $12.16 \%$ of 666 co-occurrence, involves various instrument types (e.g., incentive and information), service types (e.g., energy audit), service providers (e.g., expertise, advisor, ESCO), and service mode and design (e.g., EPC).

\section{A Critical Research Map of Homeowners' Retrofit Behaviors}

Based on the keyword groups, literature was further examined and summarized. It is derived that: (1) energy and sustainability is the basic perspective of homeowners' retrofit behaviors; (2) three groups in terms of investment-decision-energy behaviors, construction and services, and policy instruments are main research domains; (3) housing retrofit is the basic research units; and (4) theory and methodology are the knowledge base of above groups. It is worth noting that, as showed in Figure 2, these research domains are generally interrelated and interact with each other, in which homeowners' retrofit decisions play an essential role. As a result, a critical research domain map was developed in Figure 3 by further refining research domains. Detailed contents in this research map are as follows. 


\begin{tabular}{|c|c|c|c|c|c|}
\hline \multicolumn{2}{|c|}{ Research categories } & \multicolumn{4}{|c|}{ Main topics } \\
\hline \multirow{6}{*}{$\begin{array}{l}\text { Energy and } \\
\text { sustainability }\end{array}$} & $\begin{array}{l}\text { Policy } \\
\text { instruments }\end{array}$ & $\begin{array}{l}\text { - } \\
\text { - Infolicy m } \\
\text { - Incentive }\end{array}$ & $\begin{array}{l}\text { king } \\
\text { on instrument } \\
\text { instrument (e.g., subsidy, tax, financing) }\end{array}$ & & \\
\hline & $\begin{array}{c}\text { Construction and } \\
\text { services } \\
\vdots\end{array}$ & $\begin{array}{ll}\text { - } & \text { Supply-si } \\
\text { - } & \text { Types, su } \\
\text { - } & \text { Modes, s } \\
\text { - } & \text { Design ar }\end{array}$ & $\begin{array}{l}\text { Ae, e.g., expertise/craftspeople/ ESCO } \\
\text { h as energy consultation, audit, evaluatio } \\
\text { ch as energy performance certificate and } \\
\text { d process, such as homeowner participatic }\end{array}$ & $\begin{array}{l}\text { nd certification } \\
\text {-stop-shop } \\
\text { nd trust }\end{array}$ & \\
\hline & \multirow{3}{*}{ 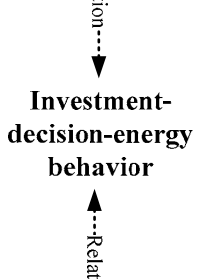 } & Investment & \multicolumn{2}{|c|}{ - Cost-effectiveness (e.g., cost, profitability, payback period) } & \multirow{4}{*}{ - Heterogeneity } \\
\hline & & $\begin{array}{l}\text { Decision- } \\
\text { making }\end{array}$ & $\begin{array}{l}\text { Decision-making process including } \\
\text { awareness, perception, attitude, } \\
\text { willingness, intention, decision, } \\
\text { implementation, and confirmation } \\
\text { - Decision support system }\end{array}$ & $\begin{array}{ll}- & \text { Motivation (e.g., economic and } \\
& \text { non-economic } \\
& \text { requirements)/drivers } \\
\text { - } & \text { Barriers } \\
- & \text { Other influencing factors }\end{array}$ & \\
\hline & & $\begin{array}{l}\text { Energy use } \\
\text { behaviors }\end{array}$ & \multicolumn{2}{|c|}{ - Energy practice, behavior change, behavioral factor } & \\
\hline & $\stackrel{\dot{v}}{\text { Housing retrofit }}$ & \multicolumn{2}{|c|}{$\begin{array}{ll}\text { - } & \text { Aesthetic retrofit } \\
\text { - } & \text { Physical retrofit } \\
\text { - } & \text { Thermal retrofit } \\
\text { - } & \text { Deep retrofit }\end{array}$} & $\begin{array}{l}\text { - Retrofit process } \\
\text { - Homeowner-based retrofit }\end{array}$ & \\
\hline
\end{tabular}

\begin{tabular}{|c|c|c|c|}
\hline \multicolumn{4}{|c|}{ Theory and methodology } \\
\hline $\begin{array}{ll}\text { - } & \text { Economy } \\
\text { - } & \text { Psychology } \\
\text { - } & \text { Society } \\
\text { - } & \text { Culture } \\
\text { - } & \text { Techomolonology }\end{array}$ & $\begin{array}{ll}\text { - } & \text { Socio-technical system } \\
\text { - } & \text { Social practice theory } \\
\text { - } & \text { Game theory } \\
\text { - } & \text { Theory of planned behavior } \\
\text { - } & \text { Motivation theory } \\
& \text { framework } \\
\text { - } & \text { Framing theory } \\
\text { - } & \text { Multi-attribute value theory } \\
\text { - } & \text { Multi-agent system }\end{array}$ & $\begin{array}{l}\text { - Optimization model } \\
\text { - } \text { Random utility model } \\
\text { - } \text { Miscrete choice } \\
\text { - } \text { Path analysis } \\
\text { - } \text { Conjoint analysis } \\
\text { - } \text { Agent-based model } \\
\text { - } \text { Pinchtecarlo } \\
\text { - Personalysis }\end{array}$ & 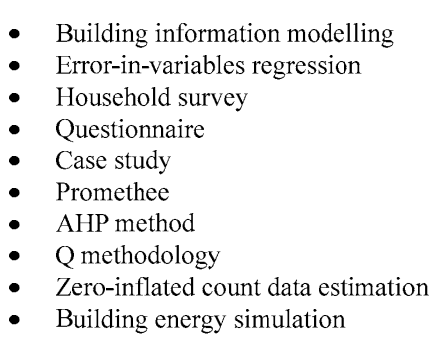 \\
\hline
\end{tabular}

Figure 3. The research map of homeowners' retrofit behaviors.

- $\quad$ Energy and sustainability

The cluster of energy and sustainability involves energy efficiency, energy performance, low-carbon, energy consumption, climate change, etc. As shown in Figure 2, energy efficiency is the most mentioned term in frequency. Compared with newly built houses, retrofitting potential houses is more beneficial for the environments and society in terms of land-saving, energy consumption, greenhouse gas emissions, and human well-being. As a result, a majority of studies highlighted that building renovation is an effective way in pursuit of sustainable development $[2,31,46]$. To achieve this goal, homeowners' retrofit behaviors become an important research branch. In this regard, sustainability is the ultimate objective of exploring homeowners' retrofit behaviors.

- Investment-decision-energy behaviors

Research on homeowners' investment-decision-energy behaviors focuses on exploring the internal logic of such behaviors and how to achieve energy-saving effects of housing renovation. In terms of investment, many studies regarded home renovation adoption as investment behaviors [47,48]. In this sense, a cost-effectiveness analysis was emphasized [49], where retrofit cost, profitability, payback period and other economic indicators were employed as main index for evaluating whether to implement home renovation. Homeowners' energy use behaviors refer to energy practice, behavior change, and be- 
havioral factors. The influence of energy use behaviors on retrofit effects is a branch of behavior research $[13,50]$. Especially, with the introduction of social practice theory, some researchers stressed that energy use behaviors should be investigated through the lens of domestic life or lifestyles [51,52].

Decision research, being complex and important for it involves a wide range of factors, is the direct antecedent to energy renovation $[9,25]$. In a broad definition, the homeowners' retrofit behaviors are the results of various decisions, covering investment decisions, adoption decisions, and behavior change decisions. A large volume of studies in collected examples focus on investment or adoption decisions of pre-retrofit, trying to explore how such decisions are made $[27,46,53]$. Initially, such decisions are assumed as rational, static and one-off. However, this hypothesis is not effective in most real-life decision situations due to limited information, limited cognitive capacities, and leaning [25,54]. To obtain an explicit representation of renovation decisions, bounded rationality (even irrationality) and dynamic processes were applied to explain homeowners' renovation decision-making. For example, Wilson, et al. [8] pointed out that the renovation decision is a process, which includes thinking about renovating, planning renovations, finalizing renovations, implementation, and experiencing renovations. Similarly, the processes, such as considering (cognitive/awareness), planning (attitude/perception), decision(intention/choice), executing, and experiencing, were adopted to understanding Dutch homeowners' renovation cognitive decision-making [27]. Another relevant research branch places an emphasis on decision support systems, which includes decision tools, decision platforms, and method development. A new method, for example, was developed by Serrano-Jiménez, et al. [13] to help homeowners identify renovation strategies. Both the decision process and decision support involve various influence factors. These factors are divide into motivation/drivers, barriers, benefits, occupant and housing characteristics, etc. (detains refer to Kastner and Stern [25] and Broers, et al. [55]).

Most importantly, previous studies identified the heterogeneous nature of homeowners' investment-decision-energy use behaviors in the process of renovation. For example, Michelsen and Madlener [56] pointed out that the influence of motivational factors on adoption decision varies across different characteristics of the homeowner and features of the home. Some studies indicated that profitability is the main motivation of home renovation for some homeowners, but other non-economic benefits, such as comfort, environment or social responsibility, might be more important for others [15,57-59]. Mortensen, et al. [60] discovered that younger generation of homeowners are more likely to be motivated to implement energy renovation than the elder. Besides of younger age, homeowners of higher income, higher education, and with environment concerns are found to be more interested in energy renovation [16]. In terms of decision processes, Broers, et al. [55] revealed that various factors play a different role in different stages of homeowners' decision-making on energy renovation, such as socio-demographic factors being important in the interesting stage and economic factors being crucial in forming opinions about retrofit technologies. That is to say, the same factor (e.g., policy instruments) might have different effects on different homeowners' renovation decisions. For these situations, heterogeneity is derived as a basic element in homeowners' investment-decision-energy behaviors.

- Construction and services

Research on construction and services pertains to a range of services provided by supply-side actors or intermediators. It covers service providers, such as craftspeople, expertise, and energy service company (ESCO); service types, such as energy audit, evaluation, and certification; service modes, such as energy performance certificate (EPC), and service design and process. For the service design and process, occupant participation is considered to be important [51]. Based on Chinese retrofit cases, Liu, et al. [34] found that lack of occupant participation may lead to a mismatch between retrofit design and homeowners' domestic life, which to some extent results in energy saving gap of housing retrofit. Most importantly, trust, connecting homeowners to supply-side actors/intermediators or information sources, is a crucial determinant for housing renovation promotion $[21,55,61]$. 
In details, three modes of trust including interpersonal trust, impersonal trust, and professional trust were identified by de Wilde [62], who revealed that the trust can be applied to improve the uptake of housing renovation.

\section{- Policy instruments}

The policy instrument is an effective strategy to promote housing renovation. There are various factors hindering housing retrofit, such as externalities, uncertainties, high initial investment, and long payback periods, which call for policy interventions and guidance [3]. By examining keywords related to policies, building retrofit policies can be divided into policy making, information instruments and incentive instruments. Among them, the two types of policies, in behavioral economics, assume that insufficient information and capital constraints are the key barriers that hinder housing renovation, which can be eliminated by providing information and economic incentives [9,12]. As a result, information instruments emphasize the supply of renovation relevant information and knowledge, aiming to reduce information asymmetry and increase homeowners' awareness of energy renovation [63]; incentive instruments mainly try to use multiple monetary means to offset the cost of housing renovation. They are the main instruments to motivate homeowners' retrofit behaviors, but also face growing criticism for their ineffectiveness [12,54]. Many studies have attempted to optimize policy making from the perspective of homeowners $[9,33,64]$. For example, Liang, et al. [64] investigated the effectiveness of different policy scenarios based on a reaction model of the government and owners, and found that the effectiveness of retrofit policies can be improved by considering owners' characteristics.

\section{- Housing retrofit}

Housing retrofit is concerned with aesthetic retrofit, physical retrofit, thermal retrofit, and deep retrofit in different house types, such as detached houses. Many studies focused on thermal retrofit, physical retrofit, and deep retrofit, which aim to improve energy efficiency $[65,66]$. Aesthetic renovations is alternative to improve the feeling of visual pleasure of house, being popular for volumes of owners [50,67]. Sunikka-Blank and Galvin [68] highlighted that homeowners' aesthetic convictions play a significant role in retrofit adoption. As a result, aesthetic renovations are considered an indispensable renovation type. Furthermore, all these renovation types involve retrofit process and various homeowners, which are considered as the common ground of the four renovation types.

- Theory and methodology

Theory and methodology, covering economy, society, culture, phenomenology, and technology, constitutes the knowledge base of homeowners' renovation behaviors. They are supported by different research theories (e.g., social practice theory, diffusion of innovation, and the theory of planned theory) and corresponding research methods (e.g., survey, optimization model and path analysis). For example, the technical perspective acknowledges the leading role of advanced technology measures (energy-efficient appliances) in shaping retrofit behaviors, focusing largely on comparative analysis of retrofit effects of different technologies. Economic discipline shares a central interest in retrofit strategies with physical technologies, and places on emphasis on cost-effectiveness by assuming rationality/bounded rationality and utility maximization. In such exploration, cost, payback, and uncertainties are dominant ingredients for explaining homeowners' renovation behaviors. Furthermore, psychology gives an attempt to probe internal factors or mechanisms of such behavior. Expanding variables such as awareness/cognition, perception/attitude, and willingness/intension were adopted. Social explorations in the field tend to emphasize homeowners' patterns of social activities where lifestyle, daily routines, social networks, or situational factors (e.g., salient events) were stressed. These perspectives witness the evolutionary process of housing renovation from technical system to eco-technical [69,70], socio-technical system [71], and socio-cultural system [72]. 


\section{Discussion}

This section integrates main research findings and presents their implications for the design of policies to achieve a sustainable built environment.

\subsection{An Integration of Domain-Specific Findings}

Drawing on above results, homeowners' retrofit behaviors involve a wider range of knowledge including culture, economy, society, technology, and psychology (in Figure 3). These provide a multidisciplinary knowledge base for homeowners' retrofit behaviors. The various emphasis of these research portrays different aspects of homeowners' retrofit behaviors, providing an effective explanation for homeowners' retrofit behaviors within a limited boundary. Nevertheless, these knowledge elements are always treated separately, creating fragmented academic results or policy practices for housing retrofit. Especially, existing policies, such as targeting economic viability or information supplying, brought litter success in motivating homeowners' retrofit behaviors and achieving expected retrofit effects $[12,24,73]$. Based on above relations of research topics (Figures 2 and 3), an integrative research framework of multiple domain-specific findings was developed as shown in Figure 4.

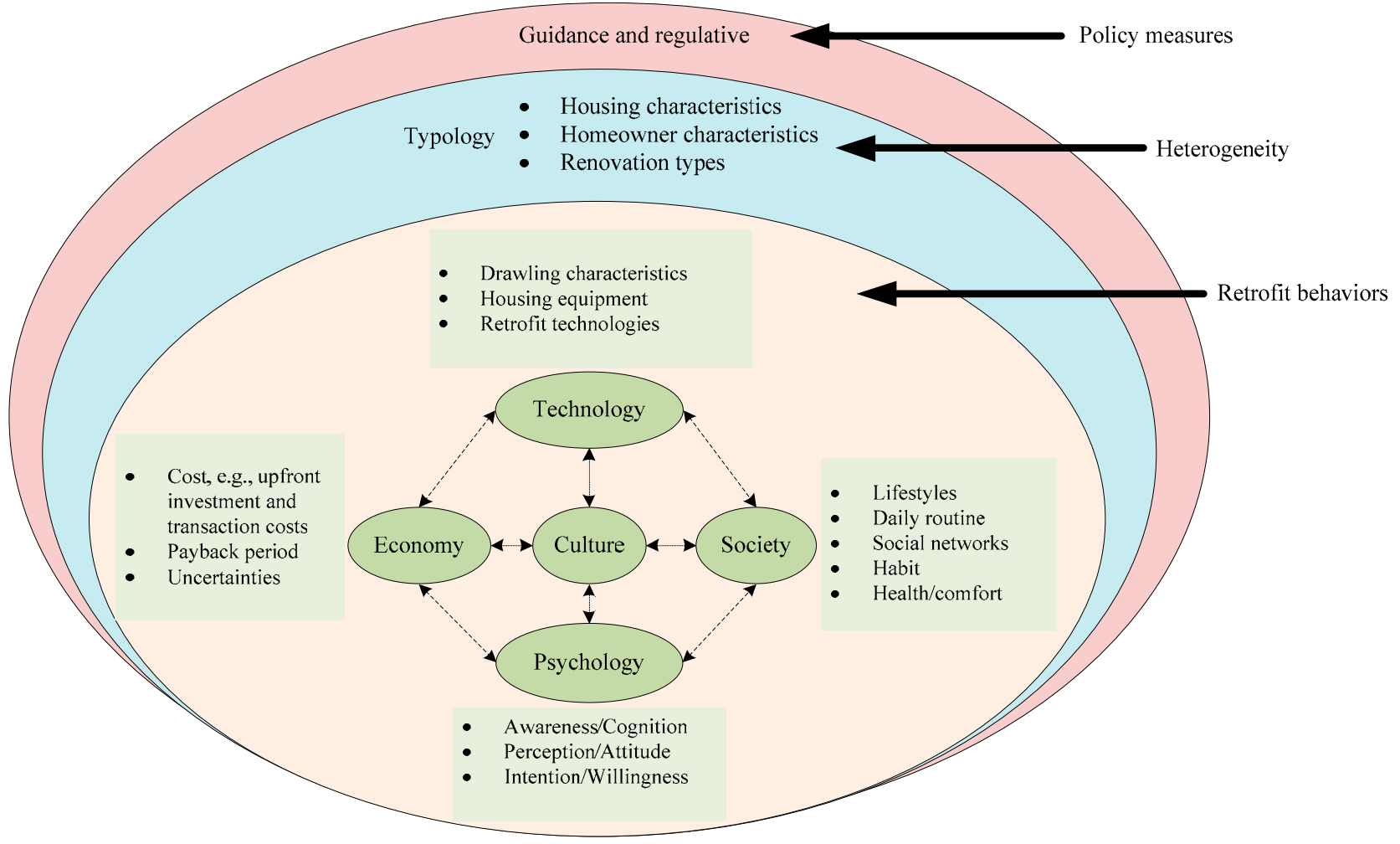

Figure 4. The integrative research framework of multiple domain-specific findings.

\section{- $\quad$ Retrofit behaviors}

As mentioned above, homeowners' retrofit behaviors in this study refer to investment decision-making behaviors of pre-retrofit, participation behaviors during retrofit process, and energy use behaviors of post-retrofit. In samples, decision-making behaviors of pre-retrofit were paid great attention. Previous studies indicated that such behaviors are shaped by a broader range of variables (e.g., technical, economic and social aspects). A good example is the application of the theory of planned behavior [74,75] in housing retrofit [76], which incorporates intentions, attitudes, subjective norms, and perceived behavioral control to explain energy investment behaviors. Another important attempt lies in the socio-technical system, which assumes that society and technology are (re)shaped 
each other in multiple dimensions and retrofit behaviors are derived from the interplay of such systems $[77,78]$. Other important domain-specific findings regarding factor relationships, such as homeowners' education levels, incomes, ages, environmental concerns, willingness, motivations, barriers, lifestyle, worldviews (altruistic or egocentric), and technology attributes, were also provided in existing studies $[8,30,67,79,80]$. These scattered research findings can be picked up in a systematic way. That is to say, homeowners' retrofit behaviors can be characterized in part by the "soft elements" coming from economic, social, and psychological domains; in part by the physical technical system including housing characteristics, house equipment and appliances, and retrofit measures, as depicted in Figure 4 .

Furthermore, such multidisciplinary research regarding homeowners' retrofit behaviors can be connected to a broader cultural context. With reference to the viewpoint of Lutzenhiser [81], homeowners' behaviors regarding energy retrofit investment and energy behavior changes are embedded in a specific culture. Such culture may be distinctive norms, practices, or material objects $[82,83]$, which create distinctions between countries and regions in terms of the way homeowners thinking about energy retrofit and energy is used [84-86]. In other words, homeowners consider housing renovation decision and energy use practices for the things that prevail within their material value, belief, and norm system $[78,87]$. In this regard, culture shapes the technical, economic, social, and especially psychological factors that condition retrofit decision and energy use practices [81]. The perspective views homeowners' retrofit behaviors as inherently and naturally results in adapting cultures, highlighting the basis of culture in shaping energy behaviors. Nevertheless, the dynamic evolution of culture is overlooked [85]. As key variables in cultural evolution, these technical, economic, social, and psychological elements have strong effects on cultural renewal and reshaping $[82,83]$. In a nutshell, these multiple perspectives and systems mutually influence each other and evolve together. As a whole, homeowners' retrofit behaviors are co-constitutive outcomes of technical, economic, social, psychological, and cultural elements.

\section{- Heterogeneity}

In addition to this, another crucial finding is that heterogeneity is an indispensable feature in the renovation process. Main results regarding heterogeneous investmentdecision-behaviors have been identified in Figure 3. As mentioned above, multidisciplinary elements do not homogenously influence every homeowner throughout the whole decisionmaking process $[27,28]$. The neglect of such heterogeneity has been considered as an important contributor to the ineffectiveness of housing renovation promotion. As a result, the heterogeneity forms the second ring of the integrated framework of homeowners' renovation behaviors, as in Figure 4.

Although many studies have pointed out the importance of decision heterogeneity, this issue has not yet been thoroughly explored, especially in the integration of multidisciplinary knowledge. As displayed in Figure 3, retrofit types cover aesthetic retrofit, physical retrofit, thermal retrofit, and deep retrofit. Such retrofit types can affect homeowners' retrofit behaviors by different retrofit processes and retrofit challenges. For example, in different retrofit types, retrofit processes might be slighting different; for deep retrofit, it may be more complicated of homeowners' retrofit decision than other types. These are common and important heterogeneous issues for homeowners' retrofit behaviors. However, scant attention is paid to the essential role of renovation types. Besides homeowners' characteristics, Ketchman et al. [15] highlighted that housing characteristics play an important role in the heterogeneous nature of homeowners' retrofit behaviors. From the perspective of technical system, as discussed above, housing characteristics has a strong effect on retrofit behaviors. Bearing these in mind, the exploration of heterogeneous features of homeowners' retrofit behaviors might expand the scopes by integrating housing characteristics, owners' characteristics, and renovation types. It is indisputable that there are many other factors strongly influencing homeowners' retrofit behaviors in a heterogeneous way. Nevertheless, dwelling characteristics, homeowners' characteristics, and renovation types can be 
regarded as the basis in the framework of topology for categorizing homeowners' retrofit behaviors. The topology in this study is useful to help understand the heterogeneity-how the multidisciplinary elements can influence different homeowners' behaviors in different housing situations and in different retrofit types.

\section{- $\quad$ Policy measures}

Policy is a specific variable affecting homeowners' retrofit behaviors by guidance and regulative instruments. Each aspect of retrofit behaviors is impacted in some way by housing renovation policies. For example, the cost barrier of housing renovation might be eliminated by monetary incentive measures; challenges of limited renovation awareness, information asymmetry and transaction cost might be resolved by effective information policies. More importantly, the introduction of new energy policy could shape household energy culture [85], available technologies, and the trends of the construction sector. As a result, policy forms an out ring of the integrative framework.

\subsection{Implications for Policies}

The essential and crucial role of homeowners played in initiating home renovation have been emphasized in many studies $[9,64,88]$. Homeowners' retrofit behaviors including retrofit investment and energy use behaviors are the key to achieve the expected retrofit effects $[6,12,13]$. However, the role of homeowners is treated by the authorities as passive recipients of retrofit ideas and technology measures [6,77], which brought little success in promoting retrofit activities. This is partly because homeowners are financial responsibility for the investment, in spite of financial support [88]; partly because the owner-occupiers interact with the house system for a long lifespan. Alternative strategy is to enhance active engagement and high involvement of homeowners in the whole process of home renovation $[34,62,78]$. Based on the results in terms of the cluster of construction and services, a set of policy efforts is need to better connect homeowners to the supply-side of renovation markets by improving relevant services (e.g., technologies, communications, procedures, trust) in line with homeowners' awareness, knowledge, and capabilities regarding renovation $[2,61]$. Most importantly, it would be feasible to advocate and enhance the compatibility of retrofitted houses with homeowners' energy use practices in pre-retrofit designs [8,73] (such as by adopting user-centered retrofit design [89]).

Apart from this, it may be helpful to expand the definition of energy retrofit by incorporating aesthetic retrofit, which is mainly led by the homeowners. Despite energy efficiency is beyond the scope of such retrofit type, aesthetic retrofit is also in pursuit of sustainability from the perspective of housing recycling or quality of life. Most importantly, aesthetic retrofit can help improve energy retrofit by enhancing homeowners' retrofit awareness and making them familiar with retrofit-related knowledge and skills.

The heterogeneous nature of homeowners' retrofit behaviors leads to different policy effects of the same policy on different individuals. As a result, it is hard to stir a wide range of homeowners' retrofit behaviors by a one-size-fits-all policy [12,33]. To solve the issue of different policy effects, some studies focus on policy redesign to improve policy effectiveness by identifying various factors (e.g., barriers, drivers) affecting homeowners' retrofit decision $[28,61]$. This may be helpful in a specific context. However, such policies may not be effective in other contexts because these factors might vary therein. Also, the effectiveness of such policies in the long-term period is worthwhile paying much attention to. Mainly because the importance of factors may change as homeowners change. For example, as the financial ability improves, the cost of retrofit measures may not be a key determinant. Such change may result in ineffectiveness of the policy designed based on financial factors. In this situation, it is important to enhance the dynamic validity of such policies. More importantly, effective policies also depend highly on targeting essential and core factors. As discussed above, homeowners' retrofit behaviors are shaped by various factors and their interactions. It would be hardly possible to design retrofit policies in reality by considering all important variables influencing homeowners' retrofit behaviors. 
With reference to the framework (Figure 4), targeting basic and important factors can be achieved under the topological framework by exploring the interrelation of various factors.

Furthermore, a main argument discussed above is that homeowners' retrofit behaviors to some extent root in a specific culture. Such culture may make homeowners lock into certain belief, value, and energy practices which play an essential role in renovation promotion $[87,90]$. When energy culture is inconsistent with energy policy, homeowners remain usually resistant to change their energy behaviors to match retrofitted housed even if such changes would lead to saving money [85]. For example, higher room temperatures in the cold season can be achieved in retrofitted houses. In this situation, many householders would rather open windows or wear lighter clothes to deal with the higher room temperatures than change device settings, which fail to achieve expected energy retrofit effects [91]. This is mainly because, for homeowners, it is often more comfortable and cost-effective by being consistent with existing energy culture [85]. As a consequence, policy design for housing retrofit should consider existing energy culture elements or shift prevailing energy cultures to match retrofit policy goals.

\section{Conclusions}

Energy conservation retrofitting of existing housing is considered an important strategy to achieve a sustainable future. To promote housing energy retrofitting at a large scale, understanding homeowners' retrofit behaviors is a key priority, yet, despite many studies, progress towards understanding homeowners' retrofit behaviors is limited by their theoretical preferences. To fill this research gap, this study makes an integrative exploration by examining and reviewing what is known about the body of research on homeowners' renovation behaviors. A keyword-based scientometric analysis was performed based on a set of 152 articles. By an in-depth analysis of 351 keywords, three main research domains, including investment-decision-energy behaviors, policy instruments, and construction and services, four retrofit types, and multiple research theories and methodologies were derived, which were mainly explored in the framing of energy and sustainability. Based on these domain-specific findings, an integrated research framework was developed. It clarifies that: (1) homeowners' retrofit behaviors are the co-constitutive outcome of technical, economic, social, psychological, cultural elements and their interactions; (2) the heterogeneity measured by dwelling characteristics, homeowners' characteristics, and renovation types can be used as a typology for targeting homeowners' retrofit behaviors; (3) the effectiveness of the retrofit policies can be improved by targeting homeowner groups, expanding the scope of energy retrofit, considering existing energy culture elements or shifting prevailing energy cultures to match retrofit policy goals.

This study might be further improved. Although multiple methods have been adopted to obtain all relevant literature as much as possible, the sample literature in this study may be still incomplete. In addition, the research categories developed for mapping related knowledge domains may not be perfect due to the nexus between categories and non-computer algorithm clustering. Nevertheless, this study provides a full knowledge picture of and develops an integrative research framework for homeowners' renovation behaviors, which a valuable reference for systematically understanding homeowners' renovation behaviors and further improving existing energy policies to mitigate environment impact and achieve a sustainable future. Also, this integrative exploration can offer an interdisciplinary starting point for future homeowner-centered retrofit research.

Author Contributions: Conceptualization, supervision, Y.T.; writing-original draft preparation, G.L.; writing-review and editing, Z.H. All authors have read and agreed to the published version of the manuscript.

Funding: This research work was supported by the National Natural Science Foundation of China (No. 72001003).

Institutional Review Board Statement: Not applicable.

Informed Consent Statement: Not applicable. 
Data Availability Statement: The data presented in this study are available on request from the corresponding author.

Acknowledgments: The author thanks Li Xiaohu for his help in visualizing keywords co-occurrence network.

Conflicts of Interest: The authors declare no conflict of interest.

\section{References}

1. Levesque, A.; Pietzcker, R.C.; Baumstark, L.; De Stercke, S.; Grübler, A.; Luderer, G. How much energy will buildings consume in 2100? A global perspective within a scenario framework. Energy 2018, 148, 514-527. [CrossRef]

2. Zundel, S.; Stieß, I. Beyond Profitability of Energy-Saving Measures-Attitudes Towards Energy Saving. J. Consum. Policy 2011, 34, 91-105. [CrossRef]

3. Liu, G.; Li, X.; Tan, Y.; Zhang, G. Building green retrofit in China: Policies, barriers and recommendations. Energy Policy 2020, 139, 11356. [CrossRef]

4. Eurostat Distribution of Population by Tenure Status, Type of Household and Income Group: EU-SILC Survey. Available online: http:/ / appsso.eurostat.ec.europa.eu/nui/show.do?dataset=ilc_lvho02\&lang=en (accessed on 20 June 2020).

5. Tan, Y.; Liu, G.; Zhang, Y.; Shuai, C.; Shen, G.Q. Green retrofit of aged residential buildings in Hong Kong: A preliminary study. Build. Environ. 2018, 143, 89-98. [CrossRef]

6. Abreu, M.I.; Oliveira, R.; Lopes, J. Attitudes and Practices of Homeowners in the Decision-making Process for Building Energy Renovation. Procedia Eng. 2017, 172, 52-59. [CrossRef]

7. Liang, X.; Peng, Y.; Shen, G.Q. A game theory based analysis of decision making for green retrofit under different occupancy types. J. Clean Prod. 2016, 137, 1300-1312. [CrossRef]

8. Wilson, C.; Pettifor, H.; Chryssochoidis, G. Quantitative modelling of why and how homeowners decide to renovate energy efficiently. Appl. Energy 2018, 212, 1333-1344. [CrossRef]

9. Wilson, C.; Crane, L.; Chryssochoidis, G. Why do homeowners renovate energy efficiently? Contrasting perspectives and implications for policy. Energy Res. Soc. Sci. 2015, 7, 12-22. [CrossRef]

10. Heiskanen, E.; Matschoss, K.; Kuusi, H. Literature Review of Key Stakeholders, Users and Investors. 2012. Available online: http:/ / www.buildup.eu/sites/default/files/content/ENTRANZE_Stakeholder\%20review.pdf (accessed on 23 December 2019).

11. Wolff, A.; Weber, I.; Gill, B.; Schubert, J.; Schneider, M. Tackling the interplay of occupants' heating practices and building physics: Insights from a German mixed methods study. Energy Res. Soc. Sci. 2017, 32, 65-75. [CrossRef]

12. Gram-Hanssen, K. Retrofitting owner-occupied housing: Remember the people. Build. Res. Inf. 2014, 42, 393-397. [CrossRef]

13. Serrano-Jiménez, A.; Lizana, J.; Molina-Huelva, M.; Barrios-Padura, Á. Decision-support method for profitable residential energy retrofitting based on energy-related occupant behaviour. J. Clean Prod. 2019, 222, 622-632. [CrossRef]

14. Nair, G.; Gustavsson, L.; Mahapatra, K. Owners perception on the adoption of building envelope energy efficiency measures in Swedish detached houses. Appl. Energy 2010, 87, 2411-2419. [CrossRef]

15. Ketchman, K.J.; Riley, D.R.; Khanna, V.; Bilec, M.M. Survey of Homeowners' Motivations for the Adoption of Energy Efficiency Measures: Evaluating a Holistic Energy Assessment Program. J. Archit. Eng. 2018, 24, 04018024. [CrossRef]

16. Pardalis, G.; Mahapatra, K.; Bravo, G.; Mainali, B. Swedish house owners' intentions towards renovations: Is there a market for one-stop-shop? Buildings 2019, 9, 164. [CrossRef]

17. Medineckiene, M.; Björk, F. Owner preferences regarding renovation measures-The demonstration of using multi-criteria decision making. J. Civ. Eng. Manag. 2011, 17, 284-295. [CrossRef]

18. Long, T.B.; Young, W.; Webber, P.; Gouldson, A.; Harwatt, H. The impact of domestic energy efficiency retrofit schemes on householder attitudes and behaviours. J. Environ. Plan. Manag. 2015, 58, 1853-1876. [CrossRef]

19. Klockner, C.A.; Nayum, A. Specific barriers and drivers in different stages of decision-making about energy efficiency upgrades in private homes. Front. Psychol. 2016, 7, 1362. [CrossRef]

20. Risholt, B.; Berker, T. Success for energy efficient renovation of dwellings-Learning from private homeowners. Energy Policy 2013, 61, 1022-1030. [CrossRef]

21. Stieß, I.; Dunkelberg, E. Objectives, barriers and occasions for energy efficient refurbishment by private homeowners. J. Clean Prod. 2013, 48, 250-259. [CrossRef]

22. Murphy, L. The influence of energy audits on the energy efficiency investments of private owner-occupied households in the Netherlands. Energy Policy 2014, 65, 398-407. [CrossRef]

23. Wilson, C.; Dowlatabadi, H. Models of Decision Making and Residential Energy Use. Annu. Rev. Environ. Resour. 2007, 32, 169-203. [CrossRef]

24. Friege, J.; Chappin, E. Modelling decisions on energy-efficient renovations: A review. Renew. Sustain. Energy Rev. 2014, 39, 196-208. [CrossRef]

25. Kastner, I.; Stern, P.C. Examining the decision-making processes behind household energy investments: A review. Energy Res. Soc. Sci. 2015, 10, 72-89. [CrossRef]

26. März, S. Beyond economics-Understanding the decision-making of German small private landlords in terms of energy efficiency investment. Energy Effic. 2018, 11, 1721-1743. [CrossRef] 
27. Ebrahimigharehbaghi, S.; Qian, Q.K.; Meijer, F.M.; Visscher, H.J. Unravelling Dutch homeowners' behaviour towards energy efficiency renovations: What drives and hinders their decision-making? Energy Policy 2019, 129, 546-561. [CrossRef]

28. Azizi, S.; Nair, G.; Olofsson, T. Analysing the house-owners' perceptions on Benefits and Barriers of energy renovation in Swedish Single-Family Houses. Energy Build. 2019, 198, 187-196. [CrossRef]

29. Palm, J.; Reindl, K. Understanding barriers to energy-efficiency renovations of multifamily dwellings. Energy Effic. 2018, 11, 53-65. [CrossRef]

30. Organ, S.; Proverbs, D.; Squires, G. Motivations for energy efficiency refurbishment in owner-occupied housing. Struct. Surv. 2013, 31, 101-120. [CrossRef]

31. Nair, G.; Gustavsson, L.; Mahapatra, K. Factors influencing energy efficiency investments in existing Swedish residential buildings. Energy Policy 2010, 38, 2956-2963. [CrossRef]

32. Juan, Y.K.; Kim, J.H.; Roper, K.; Castro-Lacouture, D. GA-based decision support system for housing condition assessment and refurbishment strategies. Autom. Constr. 2009, 18, 394-401. [CrossRef]

33. Hoicka, C.E.; Parker, P.; Andrey, J. Residential energy efficiency retrofits: How program design affects participation and outcomes. Energy Policy 2014, 65, 594-607. [CrossRef]

34. Liu, W.; Zhang, J.; Bluemling, B.; Mol, A.P.J.; Wang, C. Public participation in energy saving retrofitting of residential buildings in China. Appl. Energy 2015, 147, 287-296. [CrossRef]

35. Guerra-Santin, O.; Bosch, H.; Budde, P.; Konstantinou, T.; Boess, S.; Klein, T.; Silvester, S. Considering user profiles and occupants' behaviour on a zero energy renovation strategy for multi-family housing in the Netherlands. Energy Effic. 2018, 11, 1847-1870. [CrossRef]

36. Raynaud, M.; Osso, D.; Bourges, B.; Duplessis, B.; Adnot, J. Evidence of an indirect rebound effect with reversible heat pumps: Having air conditioning but not using it? Energy Effic. 2016, 9, 847-860. [CrossRef]

37. Elsharkawy, H.; Rutherford, P. Energy-efficient retrofit of social housing in the UK: Lessons learned from a Community Energy Saving Programme (CESP) in Nottingham. Energy Build. 2018, 172, 295-306. [CrossRef]

38. Chappin, E.J.L.; Ligtvoet, A. Transition and transformation: A bibliometric analysis of two scientific networks researching socio-technical change. Renew. Sustain. Energy Rev. 2014, 30, 715-723. [CrossRef]

39. Cecconi, R.F.; Moretti, N.; Dejaco, M.C. A Bibliometric Analysis on Costs Estimation of Building Retrofit. In Proceedings of the IOP Conference Series: Earth and Environmental Science, Central Europe towards Sustainable Building (CESB19), Prague, Czech Republic, 2-4 July 2019; Volume 290.

40. Luo, T.; Tan, Y.; Langston, C.; Xue, X. Mapping the knowledge roadmap of low carbon building: A scientometric analysis. Energy Build. 2019, 194, 163-176. [CrossRef]

41. van Eck, N.J.; Waltman, L. Visualizing Bibliometric Networks. In Measuring Scholarly Impact: Methods and Practic; Ding, R.R., Wolfram, D., Eds.; Springer: Berlin, Germany, 2014; pp. 285-320.

42. Su, H.-N.; Lee, P.-C. Mapping knowledge structure by keyword co-occurrence: A first look at journal papers in Technology Foresight. Scientometrics 2010, 85, 65-79. [CrossRef]

43. Rip, A.; Courtial, J.P. Co-word maps of biotechnology an example of cognitive scientometrics. Scienrometrics 1984, 6, 381-400. [CrossRef]

44. Shi, Y.; Liu, X. Research on the Literature of Green Building Based on the Web of Science: A Scientometric Analysis in CiteSpace (2002-2018). Sustainability 2019, 11, 3716. [CrossRef]

45. Chen, C. CiteSpace: A Practical Guide for Mapping Scientific Literature; Nova Science Publishers, Inc.: New York, NY, USA, 2016.

46. He, Q.; Zhao, H.; Shen, L.; Dong, L.; Cheng, Y.; Xu, K. Factors influencing residents' intention toward green retrofitting of existing residential buildings. Sustainability 2019, 11, 4246. [CrossRef]

47. Drivas, K.; Rozakis, S.; Xesfingi, S. The effect of house energy efficiency programs on the extensive and intensive margin of lower-income households' investment behavior. Energy Policy 2019, 128, 607-615. [CrossRef]

48. Friedman, C.; Becker, N.; Erell, E. Retrofitting residential building envelopes for energy efficiency: Motivations of individual homeowners in Israel. J. Environ. Plan. Manag. 2018, 61, 1805-1827. [CrossRef]

49. Bonakdar, F.; Kalagasidis, A.S.; Mahapatra, K. The implications of climate zones on the cost-optimal level and cost-effectiveness of building envelope energy renovation and space heat demand reduction. Buildings 2017, 7, 39. [CrossRef]

50. van den Brom, P.; Meijer, A.; Visscher, H. Actual energy saving effects of thermal renovations in dwellings-Longitudinal data analysis including building and occupant characteristics. Energy Build. 2019, 182, 251-263. [CrossRef]

51. Vlasova, L.; Gram-Hanssen, K. Incorporating inhabitants everyday practices into domestic retrofits. Build. Res. Inf. 2014, 42, 512-524. [CrossRef]

52. Maller, C.; Horne, R.; Dalton, T. Green Renovations: Intersections of Daily Routines, Housing Aspirations and Narratives of Environmental Sustainability. Hous. Theory Soc. 2012, 29, 255-275. [CrossRef]

53. Jafari, A.; Valentin, V. Decision-making life-cycle cost analysis model for energy-efficient housing retrofits. Int. J. Sustain. Build. Tech. Urban Dev. 2015, 6, 173-187. [CrossRef]

54. Fyhn, H.; Baron, N. The nature of decision making in the practice of dwelling: A practice theoretical approach to understanding maintenance and retrofitting of homes in the context of climate change. Soc. Nat. Resour. 2017, 30, 555-568. [CrossRef]

55. Broers, W.M.H.; Vasseur, V.; Kemp, R.; Abujidi, N.; Vroon, Z.A.E.P. Decided or divided? An empirical analysis of the decisionmaking process of Dutch homeowners for energy renovation measures. Energy Res. Soc. Sci. 2019, 58, 101284. [CrossRef] 
56. Michelsen, C.C.; Madlener, R. Motivational factors influencing the homeowners' decisions between residential heating systems: An empirical analysis for Germany. Energy Policy 2013, 57, 221-233. [CrossRef]

57. Booth, A.T.; Choudhary, R. Decision making under uncertainty in the retrofit analysis of the UK housing stock: Implications for the Green Deal. Energy Build. 2013, 64, 292-308. [CrossRef]

58. Haines, V.; Mitchell, V. A persona-based approach to domestic energy retrofit. Build. Res. Inf. 2014, 42, 462-476. [CrossRef]

59. Gamtessa, S.F. An explanation of residential energy-efficiency retrofit behavior in Canada. Energy Build. 2013, 57, 155-164. [CrossRef]

60. Mortensen, A.; Heiselberg, P.; Knudstrup, M. Identification of key parameters determining Danish homeowners' willingness and motivation for energy renovations. Int. J. Sustain. Built Environ. 2016, 5, 246-268. [CrossRef]

61. de Wilde, M.; Spaargaren, G. Designing trust: How strategic intermediaries choreograph homeowners' low-carbon retrofit experience. Build. Res. Inf. 2018, 47, 362-374. [CrossRef]

62. de Wilde, M. The sustainable housing question: On the role of interpersonal, impersonal and professional trust in low-carbon retrofit decisions by homeowners. Energy Res. Soc. Sci. 2019, 51, 138-147. [CrossRef]

63. Syal, M.; Duah, D.; Samuel, S.; Mazor, M.; Mo, Y.; Cyr, T. Information framework for intelligent decision support system for home energy retrofits. J. Constr. Eng. Manag. 2014, 140, 04013030. [CrossRef]

64. Liang, X.; Yu, T.; Hong, J.; Shen, G.Q. Making incentive policies more effective: An agent-based model for energy-efficiency retrofit in China. Energy Policy 2019, 126, 177-189. [CrossRef]

65. Charalambides, A.G.; Maxoulis, C.N.; Kyriacou, O.; Blakeley, E.; Frances, L.S. The impact of Energy Performance Certificates on building deep energy renovation targets. Int. J. Sustain. Energy 2019, 38, 1-12. [CrossRef]

66. Sinnott, D. Dwelling airtightness: A socio-technical evaluation in an Irish context. Build. Environ. 2016, 95, 264-271. [CrossRef]

67. Bravo, G.; Pardalis, G.; Mahapatra, K.; Mainali, B. Physical vs. aesthetic renovations: Learning from Swedish house owners. Buildings 2019, 9, 12. [CrossRef]

68. Sunikka-Blank, M.; Galvin, R. Irrational homeowners? How aesthetics and heritage values influence thermal retrofit decisions in the United Kingdom. Energy Res. Soc. Sci. 2016, 11, 97-108. [CrossRef]

69. Jafari, A.; Valentin, V. An optimization framework for building energy retrofits decision-making. Build. Environ. 2017, 115, 118-129. [CrossRef]

70. Collins, M.; Curtis, J. Value for money in energy efficiency retrofits in Ireland: Grant provider and grant recipients. Appl. Econ. 2017, 49, 5245-5267. [CrossRef]

71. Malik, J.; Bardhan, R. Energy target pinch analysis for optimising thermal comfort in low-income dwellings. J. Build. Eng. 2020, 28, 101045. [CrossRef]

72. Tjørring, L.; Gausset, Q. Drivers for retrofit: A sociocultural approach to houses and inhabitants. Build. Res. Inf. 2019, 47, 394-403. [CrossRef]

73. Galvin, R. Why German homeowners are reluctant to retrofit. Build. Res. Inf. 2014, 42, 398-408. [CrossRef]

74. Ajzen, I. From intentions to actions: A theory of planned behavior. In Action-Control: From Cognition to Behavior; Springer: Heidelberg, Germany, 1985; pp. 11-39.

75. Ajzen, I. The theory of planned behavior. Organ. Behav. Hum. Decis. Process. 1991, 50, 179-211. [CrossRef]

76. Michelsen, C.C.; Madlener, R. Integrated Theoretical Framework for a Homeowner's Decision in Favor of an Innovative Residential Heating System; (FCN Working Paper No. 2/201); Institute for Future Energy Consumer Needs and Behaviour (FCN): Aachen, Germany, 2010.

77. Galvin, R.; Sunikka-Blank, M. The UK homeowner-retrofitter as an innovator in a socio-technical system. Energy Policy 2014, 74, 655-662. [CrossRef]

78. Stieß, I.; Van der Land, V. Just another business case? Enhancing the agency for energy-efficient refurbishment among private homeowners. In Proceedings of the Knowledge Collaboration \& Learning for Sustainable Innovation ERSCP-EMSU Conference, Delft, The Netherlands, 25-29 October 2010; pp. 1-17.

79. Karvonen, A. Towards systemic domestic retrofit: A social practices approach. Build. Res. Inf. 2013, 41, 563-574. [CrossRef]

80. Michelsen, C.C.; Madlener, R. Homeowners' preferences for adopting innovative residential heating systems: A discrete choice analysis for Germany. Energy Econ. 2012, 34, 1271-1283. [CrossRef]

81. Lutzenhiser, L. A cultural model of household energy consumption. Energy 1992, 17, 47-60. [CrossRef]

82. Stephenson, J.; Barton, B.; Carrington, G.; Gnoth, D.; Lawson, R.; Thorsnes, P. Energy cultures: A framework for understanding energy behaviours. Energy Policy 2010, 38, 6120-6129. [CrossRef]

83. Stephenson, J.; Barton, B.; Carrington, G.; Doering, A.; Ford, R.; Hopkins, D.; Lawson, R.; McCarthy, A.; Rees, D.; Scott, M.; et al. The energy cultures framework: Exploring the role of norms, practices and material culture in shaping energy behaviour in New Zealand. Energy Res. Soc. Sci. 2015, 7, 117-123. [CrossRef]

84. Pettifor, H.; Wilson, C.; McCollum, D.; Edelenbosch, O.Y. Modelling social influence and cultural variation in global low-carbon vehicle transitions. Glob. Environ. Chang. 2017, 47, 76-87. [CrossRef]

85. Mahzouni, A. The institutional challenges of scaling-up housing retrofit: The Swiss cities of Basel and Sion. Facilities 2019, 37, 780-798. [CrossRef]

86. Poortinga, W.; Steg, L.; Vlek, C. Values, Environmental Concern, and Environmental Behavior. Environ. Behav. 2004, $36,70-93$. [CrossRef] 
87. Rau, H.; Moran, P.; Manton, R.; Goggins, J. Changing energy cultures? Household energy use before and after a building energy efficiency retrofit. Sustain. Cities Soc. 2020, 54, 101983. [CrossRef]

88. Matschoss, K.; Heiskanen, E.; Atanasiu, B.; Kranzl, L. Energy renovations of EU multifamily buildings: Do current policies target the real problems. In Proceedings of the ECEEE, Hyères, France, 3-8 June 2013; pp. 1485-1496.

89. Lucchi, E.; Delera, A.C. Enhancing the Historic Public Social Housing through a User-Centered Design-Driven Approach. Buildings 2020, 10, 159. [CrossRef]

90. Bartiaux, F.; Gram-Hanssen, K.; Fonseca, P.; Ozolina, L.; Christensen, T.H. A practice-theory approach to homeowners' energy retrofits in four European areas. Build. Res. Inf. 2014, 42, 525-538. [CrossRef]

91. Galassi, V.; Madlener, R. Shall I open the window? Policy implications of thermal-comfort adjustment practices in residential buildings. Energy Policy 2018, 119, 518-527. [CrossRef] 